УДК 664.7.004.12:633.11

(C) 2017

Господаренко Г. М., доктор сільськогосподарських наук, Любич В. В., кандидат сільськогосподарських наук, Полянецька І. О., кандидат сільськогосподарських наук Уманський національний університет садівництва

\title{
ВИХІД І ЯКІСТЬ КРУП'ЯНИХ ПРОДУКТІВ ІЗ ЗЕРНА СОРТІВ І ЛІНІЙ ПШЕНИЦЬ
}

\section{Рецензент - доктор сільськогосподарських наук Ю. Ф. Терещенко}

У статті наведено результати вивчення вмісту анатомічних складових у зернівці сортів $і$ ліній пшениць, вихід і кулінарне оцінювання круп'яних продуктів. Встановлено, щчо високий вихід крупи (85-89\%) та високу кулінарну оиінку (7-9 балів) має зерно сортів пшениці м'якої Ужинок, Вдала, Щедра нива, Паннонікус, Емеріно, Лупус, лінії пшениці шільноколосої Уманчанка $i$ ліній, отриманих гібридизацією Tr. aestivum / Tr. spelta. Екструдування зерна пшениць істотно покрашує кулінарну оцінку готового продукту завдяки температурному обробленню. Зерно сортів Кохана, Вдала, Лупус, Емеріно, Паннонікус, Ac Meckinon, Кулундинка, лінії Уманчанка та ліній пшениці м'якої озимої використовувати для екструдування без його лущчення.

Ключові слова: пшениия м'яка, щиільноколоса, ефіопська, крупа, кулінарна очінка, екструдат, лущення зерна.

Постановка проблеми. Крупи посідають чільне місце в національній економіці. Відповідно до фізіологічних норм денний раціон людини повинен містити близько 40 г круп'яних продуктів, що відповідає споживанню 14-15 кг на рік [4]. Крім цього зернові продукти забезпечують близько 30 \% потреби в енергії за рахунок вмісту в їхньому складі $30 \%$ білка і $55 \%$ вуглеводів [10]. Проте ці продукти зазвичай містять недостатній вміст білка. Одним зі шляхів його вирішення $є$ пошук альтернативних видів зернової сировини 3 його високим вмістом [2]. Перспективною є розробка круп'яних продуктів із зерна малопоширених видів пшениці.

Аналіз останніх досліджень i публікацій, у яких започатковано розв'язання проблеми. Встановлено, що круп'яні продукти із зерна пшениці м'якої характеризуються доброю та відмінною якістю, проте на загальну кулінарну оцінку впливають консистенція, смак і колір каші [6].

Зерно пшениці щільноколосої, ефіопської, сорти пшениці м'якої, отримані міжвидовою та міжродовою гібридизацією, $є$ перспективною сировиною для виробництва крупи, борошна, випікання хлібобулочних виробів, сухої клейко- вини, спирту, що вимагає специфічних технологічних властивостей зерна для отримання цих продуктів [3]. Проте дослідження таких якостей проводилось лише на початку минулого століття 3 місцевими іiі формами. Крім цього серед інших продуктів крупа посідає важливе місце у харчуванні. У 2003 р. в Україні було виготовлено 294 тис. т круп'яних продуктів, а в 2015 р. 347 тис. т [12]. Якість крупи визначається їі хімічним складом, технологічними та споживними властивостями. Особливістю хімічного складу крупи є вищий вміст вуглеводів (65-77\%), тому 1ii енергетична цінність становить 1,3-1,5 МДж у 100 г [7].

Отже, в умовах постійного зростання сортименту пшениці дослідження можливості та доцільності виробництва круп'яних продуктів, визначення їх кулінарних властивостей $є$ актуальним.

Мета досліджень - вивчення круп'яних властивостей зерна сортів і ліній пшениць.

Матеріали і методи досліджень. Експериментальну частину роботи проводили в лабораторії «Оцінювання якості зерна та зернопродуктів» кафедри технології зберігання i переробки зерна Уманського національного університету садівництва. Використовували зерно сортів пшениці м'якої: Подолянка, Вікторія одеська, Ластівка одеська, Ужинок, Кохана, Вдала, 3 фіолетовим забарвленням зернівки Чорноброва, створених в умовах Степу; Щедра нива, Мирхад, Славна, створених в умовах Лісостепу; селекції країн Європи Паннонікус (Австрія), Емеріно (Кіпр), Лупус (Австрія), Суасон (Франція), білозерної Кулундинка (Росія), Аc Meckinon (Канада); лінія пшениці щільноколосої Уманчанка, пшениці ефіопської ярої Ефіопська 1, лінії, отримані гібридизацією Triticum aestivum/ Triticum spelta LPP 2793, LPP 1314, LPP 3118, P 7 та інтрогресивні лінії NAK 46/12 і NAK 61/12, отримані гібридизацією Triticum aestivum / амфіплоїд (Triticum durum / Ae. tauschii), що вирощувалися в умовах Правобережного Лісостепу України. Контролем (стандартом) був районований сорт пшениці 
м'якої (національний стандарт) Подолянка (st).

Вміст ендосперму визначали за вдосконаленою методикою, описаною в патенті на корисну модель «Спосіб визначення вмісту ендосперму в зерні тритикале та пшениці» № u 201606341 (Господаренко Г. М., Любич В. В., Новіков В. В. та ін., 2016), оцінювання круп'яних продуктів «Спосіб кулінарної оцінки круп'яних продуктів iз зерна тритикале i пшениці» № u 201507630 (Господаренко Г. М., Любич В. В., Новіков В. В. та ін., 2016), оцінювання крупи манної - «Спосіб кулінарної оцінки крупи манної із зерна тритикале та пшениці» № u 201608016 (Любич В. В., Господаренко Г. М., Полянецька І. О., 2016$)$, оцінювання екструдату - «Спосіб кулінарної оцінки екструдату з круп'яних продуктів тритикале та пшениці» № u 201608019 (Любич В. В., Господаренко Г. М., Полянецька І. О., 2016).

Крупу з пшениці спельти №1 отримували лущенням зволоженого зерна в лабораторному лущильнику УШЗ-1, крупу із пшениці спельти подрібнену - 3 крупи цілої на універсальній крупорушці УКР-2, плющену крупу - 3 лущеної крупи (початкова вологість $14 \%$ ) пропарюванням упродовж 5-15 хв. за сталого тиску насиче-

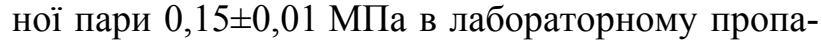
рнику періодичної дії (ППД-1). Вихід крупи цілої наведено у відсотках до 100 г зерна, плющеної - до відповідної маси лущеної крупи, подрібнених - до 100 г цілої крупи. Екструдат отримували з лущеного та нелущеного зерна в лабораторному експандері за температури 130$150{ }^{\circ} \mathrm{C}$. Індекс лущення змінювався залежно від вмісту оболонок. Крупу манну отримували лабораторним розмелюванням зерна після другої драної системи.

Математичну обробку даних проводили методом однофакторного дисперсійного аналізу [5]. Для оцінювання тісноти зв'язку між показниками, що вивчалися, використовували шкалу R. E. Chaddock [8], яка за величини коефіцієнта кореляції 0,1-0,3 - слабка, 0,3-0,5 - помірна, 0,5-0,7 - істотна, 0,7-0,9висока, 0,9-0,99 - дуже висока.

Результати досліджень. Результати досліджень свідчать, що вміст анатомічних складових змінювався залежно від сорту та лінії пшениць (табл. 1). Так, вміст ендосперму у зерні сортів пшениці м'якої озимої був від 81,7 до 87,8 \%, проте істотно вищим - лише у п'яти сортів: Вдала, Кохана, Паннонікус, Емеріно і Лупус $\left(\mathrm{HIP}_{05}=4,1\right)$.

\section{1. Вміст анатомічних складових зернівки сортів і ліній пшениць, \%}

\begin{tabular}{|c|c|c|c|c|c|c|}
\hline \multirow{2}{*}{ Сорт, лінія } & \multicolumn{6}{|c|}{ Вміст } \\
\hline & ендосперму & до st, \pm & оболонок & до st, \pm & зародку & до st, \pm \\
\hline Подолянка (st) & 81,7 & - & 16,4 & - & 1,9 & - \\
\hline Ластівка одеська & 83,2 & 1,5 & 15,1 & $-1,3$ & 1,7 & $-0,2$ \\
\hline Ужинок & 84,4 & 2,7 & 13,8 & $-2,6$ & 1,8 & $-0,1$ \\
\hline Вікторія одеська & 84,6 & 2,9 & 13,9 & $-2,5$ & 1,5 & $-0,4$ \\
\hline Вдала & 86,2 & 4,5 & 12,1 & $-4,3$ & 1,7 & $-0,2$ \\
\hline Кохана & 87,2 & 5,5 & 10,8 & $-5,6$ & 2,0 & 0,1 \\
\hline Мирхад & 82,8 & 1,1 & 15,7 & $-0,7$ & 1,5 & $-0,4$ \\
\hline Щедра нива & 83,3 & 1,6 & 15,1 & $-1,3$ & 1,6 & $-0,3$ \\
\hline Славна & 84,9 & 3,2 & 13,0 & $-3,4$ & 2,1 & 0,2 \\
\hline Суасон & 84,2 & 2,5 & 13,7 & $-2,7$ & 2,1 & 0,2 \\
\hline Паннонікус & 85,1 & 3,4 & 12,9 & $-3,5$ & 2,0 & 0,1 \\
\hline Емеріно & 87,2 & 5,5 & 11,4 & $-5,0$ & 1,4 & $-0,5$ \\
\hline Лупус & 87,8 & 6,1 & 10,0 & $-6,4$ & 2,2 & 0,3 \\
\hline Ефіопська 1 & 79,8 & $-1,9$ & 17,8 & 1,4 & 2,4 & 0,5 \\
\hline Чорноброва & 80,8 & $-0,9$ & 17,1 & 0,7 & 2,1 & 0,2 \\
\hline Кулундинка & 82,1 & 0,4 & 16,2 & $-0,2$ & 1,7 & $-0,2$ \\
\hline Ac Meckinon & 84,8 & 3,1 & 13,4 & $-3,0$ & 1,8 & $-0,1$ \\
\hline Уманчанка & 86,0 & 4,3 & 12,6 & $-3,8$ & 1,4 & $-0,5$ \\
\hline P 7 & 86,4 & 4,7 & 12,2 & $-4,2$ & 1,4 & $-0,5$ \\
\hline LPP 1314 & 87,1 & 5,4 & 11,5 & $-4,9$ & 1,4 & $-0,5$ \\
\hline LPP 2793 & 87,4 & 5,7 & 11,3 & $-5,1$ & 1,3 & $-0,6$ \\
\hline LPP 3118 & 87,8 & 6,1 & 10,9 & $-5,5$ & 1,3 & $-0,6$ \\
\hline NAK61/12 & 84,2 & 2,5 & 14,1 & $-2,3$ & 1,7 & $-0,2$ \\
\hline NAK46/12 & 85,0 & 3,3 & 13,4 & $-3,0$ & 1,6 & $-0,3$ \\
\hline$H I P_{05}$ & 4,1 & - & 0,7 & - & 0,1 & - \\
\hline
\end{tabular}




\section{СІЛЬСЬКЕ ГОСПОДАРСТВО. РОСЛИННИЦТВО}

Зерно пшениці щільноколосої Уманчанка, лінії пшениці м'якої озимої, отримані гібридизаці$є ю$ Triticum aestivum / Triticum spelta та інтрогресивної лінії NAK 46/12 також характеризувалось істотно вищим вмістом ендосперму, який змінювався від 85,0 до 87,8 \%. Найнижчий вміст ендосперму мали зернівки лінії пшениці ефіопської Ефіопська 1 - 79,8 \%. Вміст оболонок змінювався від 10,0 до 17,8 \%, а вміст зародку - від 1,3 до 2,4 \% залежно від сорту та лінії пшениць.

Встановлено, що найвищим був вихід крупи 3 пшениці № 1, який істотно змінювався залежно від сорту та лінії. Так, найвищий їі вихід отримано із зерна сортів Вдала, Кохана, Емеріно та Лупус - 87,4-88,6 \% (табл. 2). Зерно лінії пшениці щільноколосої Уманчанка, ліній Р 3, LPP 1304, LPP 3122/2, LPP 3117, LPP 3373, отримані гібридизацією Tr. aestivum / Tr. spelta та інтрогресивної лінії NAK 46/12 також харак- теризувалось високим виходом - від 86,7 до 89,1 \%. Цей показник у решти сортів і ліній змінювався від 80,7 до 86,2 \%. Тенденція виходу плющеної крупи була подібною до виходу цілої крупи, показник якої змінювався від 79,3 до $87,7 \%$.

Вихід подрібнених круп був найнижчим і змінювався від 78,0 до 86,1%. Слід зазначити, що в складі подрібнених круп найвищим був вихід крупи подрібненої № 2 - 53,4-59,1\%, найнижчим - крупи подрібненої №1 (9,8-10,8 \%).

Між виходом крупи 3 пшениці №1 і вмістом ендосперму в зернівці встановлено дуже високу (r=0,93) кореляційну залежність, яка описується таким рівнянням регресії:

$\mathrm{Y}=1,0405 \mathrm{x}-2,0344$,

де у - вихід крупи з пшениці № 1, \%;

$\mathrm{x}$ - вміст ендосперму в зернівці, \% (рис. 1).

\section{2. Вихід круп'яних продуктів із зерна сортів і ліній пшениць, \%}

\begin{tabular}{|c|c|c|c|c|c|c|}
\hline \multirow{3}{*}{ Сорт, лінія } & \multicolumn{6}{|c|}{ Вихід крупи } \\
\hline & \multirow{2}{*}{ № 1} & \multicolumn{4}{|c|}{ подрібненої } & \multirow{2}{*}{ плющеної } \\
\hline & & № 1 & № 2 & № 3 & всього & \\
\hline Подолянка (st) & 82,3 & 9,9 & 54,3 & 14,8 & 79,0 & 79,4 \\
\hline Ластівка одеська & 84,1 & 10,2 & 55,6 & 15,3 & 81,1 & 82,1 \\
\hline Вікторія одеська & 85,8 & 10,3 & 56,9 & 15,8 & 83,0 & 82,5 \\
\hline Ужинок & 86,2 & 10,5 & 57,1 & 16,1 & 83,7 & 84,6 \\
\hline Вдала & 87,4 & 10,8 & 58,0 & 15,9 & 84,7 & 84,3 \\
\hline Кохана & 88,6 & 10,7 & 58,9 & 16,2 & 85,9 & 85,3 \\
\hline Щедра нива & 85,6 & 10,3 & 56,7 & 15,4 & 82,3 & 83,1 \\
\hline Мирхад & 86,1 & 10,6 & 57,2 & 15,8 & 83,6 & 82,9 \\
\hline Славна & 86,4 & 10,7 & 57,3 & 16,2 & 84,2 & 83,1 \\
\hline Суасон & 85,0 & 10,3 & 56,4 & 15,3 & 81,9 & 81,9 \\
\hline Паннонікус & 86,5 & 10,4 & 57,2 & 15,7 & 83,3 & 84,9 \\
\hline Емеріно & 88,7 & 10,6 & 58,7 & 16,4 & 85,8 & 85,2 \\
\hline Лупус & 89,1 & 11,0 & 58,8 & 16,1 & 85,9 & 87,1 \\
\hline Ефіопська 1 & 80,7 & 9,9 & 53,4 & 14,7 & 78,0 & 79,3 \\
\hline Чорноброва & 81,3 & 9,8 & 54,2 & 14,6 & 78,7 & 78,5 \\
\hline Кулундинка & 83,1 & 10,0 & 55,2 & 15,2 & 80,4 & 81,6 \\
\hline Ac Meckinon & 86,2 & 10,7 & 57,1 & 15,9 & 83,6 & 84,1 \\
\hline Уманчанка & 87,6 & 10,6 & 58,1 & 16,2 & 84,9 & 85,9 \\
\hline P 7 & 87,5 & 10,7 & 58,1 & 15,8 & 84,5 & 85,5 \\
\hline LPP 1314 & 88,4 & 10,9 & 58,3 & 16,3 & 85,5 & 86,9 \\
\hline LPP 2793 & 89,0 & 10,7 & 58,8 & 16,0 & 85,5 & 87,4 \\
\hline LPP 3118 & 89,1 & 10,8 & 59,1 & 16,2 & 86,1 & 87,7 \\
\hline NAK61/12 & 86,2 & 10,5 & 57,0 & 15,7 & 83,2 & 83,4 \\
\hline NAK46/12 & 86,7 & 10,7 & 57,7 & 16,0 & 84,3 & 84,4 \\
\hline$H I P_{05}$ & 4,3 & 0,5 & 2,8 & 0,7 & 4,0 & 4,3 \\
\hline
\end{tabular}




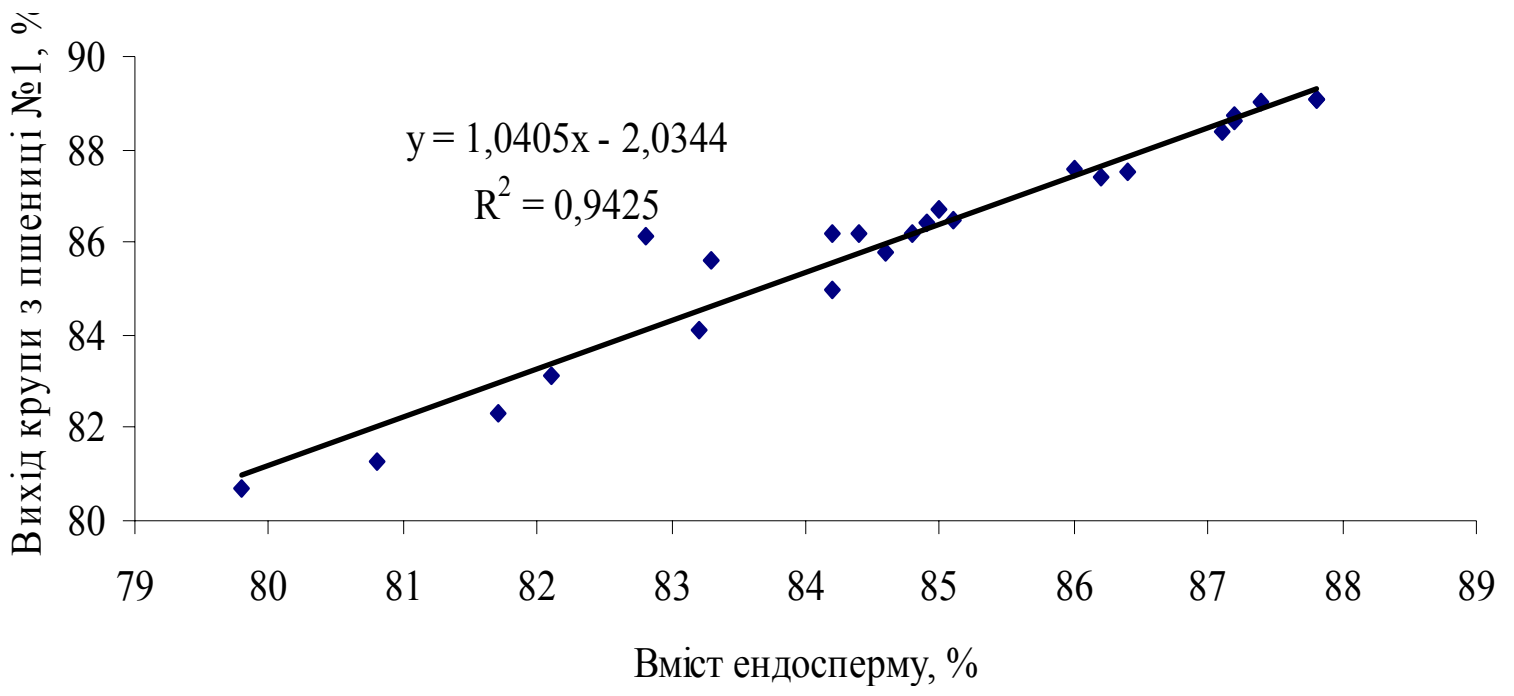

Рис. 1. Кореляційна залежність між виходом крупи з пшениці № 1 і вмістом ендосперму в зернівці

3. Кулінарна оцінка крупи з пшениці № 1, подрібненої №1, №2, №3 і плющееної залежно від сорту та лінї, бал

\begin{tabular}{|c|c|c|c|c|c|c|}
\hline Сорт, лінія & 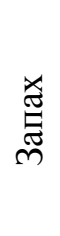 & 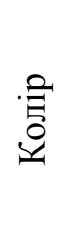 & 己ِّ & 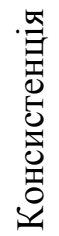 & $\begin{array}{l}\text { Консистенція під } \\
\text { час розжовування }\end{array}$ & $\begin{array}{c}\text { Загальна } \\
\text { кулінарна оцінка }\end{array}$ \\
\hline Подолянка (st) & 7 & 9 & 7 & 9 & 9 & 8,2 \\
\hline Кохана & 3 & 9 & 3 & 5 & 9 & 5,8 \\
\hline Ластівка одеська & 5 & 9 & 5 & 5 & 9 & 6,6 \\
\hline Вікторія одеська & 7 & 9 & 7 & 7 & 9 & 7,8 \\
\hline Вдала & 7 & 9 & 7 & 7 & 9 & 7,8 \\
\hline Ужинок & 9 & 9 & 7 & 9 & 9 & 8,6 \\
\hline Славна & 5 & 9 & 3 & 5 & 9 & 6,2 \\
\hline Мирхад & 5 & 9 & 5 & 5 & 9 & 6,6 \\
\hline Щедра нива & 7 & 9 & 7 & 7 & 9 & 7,8 \\
\hline Суасон & 7 & 9 & 7 & 9 & 9 & 8,2 \\
\hline Емеріно & 9 & 9 & 9 & 9 & 9 & 9,0 \\
\hline Лупус & 9 & 9 & 9 & 9 & 9 & 9,0 \\
\hline Паннонікус & 9 & 9 & 9 & 9 & 9 & 9,0 \\
\hline Ac Meckinon & 5 & 9 & 5 & 5 & 9 & 6,6 \\
\hline Чорноброва & 9 & - & 5 & 7 & 9 & 7,5 \\
\hline Ефіопська 1 & 9 & - & 5 & 9 & 9 & 8,0 \\
\hline Уманчанка & 9 & 9 & 9 & 7 & 9 & 8,6 \\
\hline Кулундинка & 9 & 9 & 9 & 9 & 9 & 9,0 \\
\hline LPP 2793 & 9 & 9 & 9 & 9 & 9 & 9,0 \\
\hline LPP 1314 & 9 & 9 & 9 & 9 & 9 & 9,0 \\
\hline LPP 3118 & 9 & 9 & 9 & 9 & 9 & 9,0 \\
\hline P 7 & 9 & 9 & 9 & 9 & 9 & 9,0 \\
\hline NAK46/12 & 7 & 9 & 5 & 5 & 9 & 7,0 \\
\hline NAK61/12 & 7 & 9 & 7 & 7 & 9 & 7,8 \\
\hline$H I P_{05}$ & 1 & 1 & 1 & 1 & 1 & 0,3 \\
\hline
\end{tabular}




\section{СІЛЬСЬКЕ ГОСПОДАРСТВО. РОСЛИННИЦТВО}

Органолептичні властивості крупи оцінюють за якістю каші та визначають колір, смак, структуру, тривалість варіння, коефіцієнт розварювання та консистенцію [9]. Набухання часточок крупи під час варіння зумовлено деструкцією геміцелюлози, екстенсину, набухання крохмалю і меншою мірою розпадом протопектину [11].

Встановлено, що органолептична оцінка каші 3 круп'яних продуктів зерна пшениць істотно змінювалась залежно від сорту та лінії (табл. 3). Так, сильно виражений запах (9 балів) мала каша, отримана 3 крупи 12 сортів і ліній, виражений (7 балів) - семи, слабо виражений (5 балів) чотирьох сортів і ліній. Відсутній запах мала каша, отримана 3 крупи зерна сорту Кохана 3 бали. Встановлено, що походження сорту та лінії не впливало на показник кольору каші, який був світло-кремовим 3 жовтим відтінком. Колір каші з крупи сорту пшениці Чорноброва та лінії Ефіопська 1 був з фіолетовим відтінком завдяки вмісту антоціанового забарвлення, тому іiі не оцінювали.

Смак каші $з$ крупи пшениць змінювався ана- логічно показникам запаху. Найвищу оцінку за цим показником мала каша, отримана 3 крупи зерна сортів Емеріно, Лупус, Паннонікус, Кулундинка та ліній, отримані гібридизацією $T r$. aestivum / Tr. spelta, і лінія пшениці ефіопської Ефіопська 1-9 балів.

Розсипчасту консистенцію (9 балів) мала каша отримана 3 крупи пшениці сортів Подолянка, Ужинок, Суасон, Емеріно, Лупус і Паннонікус, ліній, отримані гібридизацією Tr. aestivum / Tr. spelta, і лінії пшениці ефіопської Ефіопська 1. Каша 3 крупи зерна сортів Вікторія одеська, Вдала, Щедра нива, Чорноброва і ліній Уманчанка та NAK 61/12 мала слабо розсипчасту консистенцію (7 балів), а каша 3 крупи зерна решти сортів була слабо розсипчастою з грудочками. За показником розжовування каша з крупи пшениці була дуже ніжною та мала найвищу кулінарну оцінку - 9 балів.

Вважається, що загальна кулінарна оцінка 3 показників 8,0-9,0 балів - дуже висока, 6,6-8,0 висока, 5,4-6,6 - середня, 4,0-5,4 - низька, $<$ 4,0 балів - дуже низька.

\section{4. Кулінарна оцінка крупи манної з пшениці залежно від сорту, бал}

\begin{tabular}{|l|c|c|c|c|c|}
\hline \multicolumn{1}{|c|}{ Сорт, лінія } & Запах & Колір & Смак & Консистенція & $\begin{array}{c}\text { Загальна } \\
\text { кулінарна } \\
\text { оцінка }\end{array}$ \\
\hline Подолянка (st) & 7 & 7 & 7 & 7 & 7,0 \\
\hline Кохана & 3 & 7 & 3 & 3 & 4,0 \\
\hline Ластівка одеська & 5 & 7 & 5 & 3 & 5,0 \\
\hline Вікторія одеська & 7 & 7 & 7 & 7 & 7,0 \\
\hline Вдала & 7 & 7 & 7 & 7 & 7,0 \\
\hline Ужинок & 9 & 7 & 7 & 7 & 7,5 \\
\hline Славна & 5 & 7 & 3 & 5 & 5,0 \\
\hline Мирхад & 5 & 7 & 5 & 5 & 5,5 \\
\hline Щедра нива & 7 & 7 & 7 & 7 & 7,0 \\
\hline Лупус & 5 & 7 & 9 & 7 & 7,0 \\
\hline Суасон & 9 & 7 & 7 & 7 & 7,5 \\
\hline Емеріно & 9 & 7 & 9 & 9 & 8,5 \\
\hline Паннонікус & 9 & 7 & 9 & 9 & 8,5 \\
\hline Ас Мескіпо & 5 & 9 & 5 & 3 & 5,5 \\
\hline Ефіопська 1 & 9 & - & 3 & 5 & 5,7 \\
\hline Чорноброва & 9 & - & 3 & 7 & 6,3 \\
\hline Уманчанка & 9 & 9 & 7 & 7 & 8,0 \\
\hline Кулундинка & 9 & 9 & 9 & 7 & 8,5 \\
\hline Р 7 & 9 & 9 & 7 & 5 & 7,5 \\
\hline LРP 1314 & 9 & 9 & 9 & 7 & 8,5 \\
\hline LРP 2793 & 9 & 9 & 9 & 9 & 9,0 \\
\hline LРP 3118 & 9 & 9 & 9 & 9 & 9,0 \\
\hline NAК46/12 & 7 & 7 & 5 & 5 & 6,0 \\
\hline NAК61/12 & 7 & 7 & 7 & 5 & 6,5 \\
\hline \multicolumn{1}{|c|}{ HIP 05} & 1 & 1 & 1 & 1 & 0,3 \\
\hline
\end{tabular}




\section{СІЛЬСЬКЕ ГОСПОДАРСТВО. РОСЛИННИЦТВО}

Результати досліджень свідчать, що загальна кулінарна оцінка істотно змінювалась залежно від сорту та лінії пшениці. Дуже високу кулінарну оцінку мала крупа зерна сортів пшениці м'якої Подолянка, Ужинок, Суасон, Емеріно, Лупус, Паннонікус і Кулундинка, лінії, отримані гібридизацією Tr. aestivum / Tr. spelta, пшениці ефіопської та щільноколосої. Крупа, отримана із зерна семи сортів пшениці м'якої озимої та ліній, отриманих гібридизацією Triticum aestivum / амфіплоїд (Triticum durum / Ae. tauschii), мала високу оцінку, а решти сортів середню.Запах і смак каші з крупи манної змінювався аналогічно показникам цілої та дробленої крупи (табл. 4). Проте каша із зерна сортів Ac Meckinon i Кулундинка та ліній, отриманих гібридизацією Tr. aestivum / Tr. spelta, була світло-кремовою колір, а в решти форм злегка темнішою. В'язку та однорідну консистенцію (9 балів) отримано з крупи манної сортів Емері- но та Паннонікус і ліній LPP 3118, LPP 2793. Напівв'язку та однорідну консистенцію (7 балів) мала каша 3 крупи манної дев'яти сортів і двох ліній. Пастоподібною (3 бали) була каша 3 крупи сортів Кохана та Ластівка одеська.

Дуже високу кулінарну оцінку мала крупа манна, отримана із зерна сортів Емеріно, Паннонікус і Кулундинка та лінії, отримані гібридизацією Tr. aestivum / Tr. spelta, і пшениця щільноколоса. Крупа манна, отримана із зерна семи сортів пшениці м'якої озимої та лінії Р 7 мала високу кулінарну оцінку - 7,0-8,0 балів. Дуже низьку кулінарну оцінку мала крупа із зерна сортів Кохана, Ластівка одеська, Славна, Мирхад і Ас Meckinon - 4,0-5,4 балів.

Дослідженнями встановлено, що запах і смак екструдату $з$ лущеного та нелущеного зерна був сильно вираженим (9 балів) і не змінювався залежно від сорту та лінії (табл. 5).

\section{5. Кулінарна оцінка екструдату із зерна сортів іліній пшениці, бал}

\begin{tabular}{|c|c|c|c|c|c|c|c|c|c|c|}
\hline \multirow[t]{2}{*}{ Сорт, лінія } & \multicolumn{2}{|c|}{ Запах } & \multicolumn{2}{|c|}{ Колір } & \multicolumn{2}{|c|}{ Смак } & \multicolumn{2}{|c|}{$\begin{array}{c}\text { Консистенція } \\
\text { під час роз- } \\
\text { жовування }\end{array}$} & \multicolumn{2}{|c|}{$\begin{array}{c}\text { Загальна ку- } \\
\text { лінарна оцін- } \\
\text { ка }\end{array}$} \\
\hline & 1 & 2 & 1 & 2 & 1 & 2 & 1 & 2 & 1 & 2 \\
\hline Подолянка (st) & 9 & 9 & 3 & 5 & 9 & 9 & 5 & 9 & 6,5 & 8,0 \\
\hline Ластівка одеська & 9 & 7 & 3 & 5 & 9 & 9 & 7 & 9 & 7,0 & 7,5 \\
\hline Кохана & 9 & 7 & 5 & 5 & 9 & 9 & 9 & 9 & 8,0 & 7,5 \\
\hline Ужинок & 9 & 9 & 3 & 5 & 9 & 9 & 7 & 9 & 7,0 & 8,0 \\
\hline Вікторія одеська & 9 & 9 & 3 & 5 & 9 & 9 & 7 & 9 & 7,0 & 8,0 \\
\hline Вдала & 9 & 9 & 5 & 5 & 9 & 9 & 9 & 9 & 8,0 & 8,0 \\
\hline Славна & 9 & 7 & 5 & 5 & 9 & 9 & 7 & 9 & 7,5 & 7,5 \\
\hline Мирхад & 9 & 7 & 3 & 5 & 9 & 9 & 5 & 9 & 6,5 & 7,5 \\
\hline Щедра нива & 9 & 9 & 3 & 5 & 9 & 9 & 7 & 9 & 7,0 & 8,0 \\
\hline Суасон & 9 & 9 & 3 & 5 & 9 & 9 & 7 & 9 & 7,0 & 8,0 \\
\hline Лупус & 9 & 9 & 5 & 5 & 9 & 9 & 9 & 9 & 8,0 & 8,0 \\
\hline Емеріно & 9 & 9 & 5 & 7 & 9 & 9 & 9 & 9 & 8,0 & 8,5 \\
\hline Паннонікус & 9 & 9 & 9 & 9 & 9 & 9 & 9 & 9 & 9,0 & 9,0 \\
\hline Чорноброва & 9 & 9 & 3 & 5 & 9 & 9 & 5 & 9 & 6,5 & 8,0 \\
\hline Ефіопська 1 & 9 & 9 & 3 & 5 & 9 & 9 & 5 & 9 & 6,5 & 8,0 \\
\hline Ac Meckinon & 9 & 7 & 9 & 9 & 9 & 9 & 7 & 9 & 8,5 & 8,5 \\
\hline Кулундинка & 9 & 9 & 9 & 9 & 9 & 9 & 5 & 9 & 8,0 & 9,0 \\
\hline Уманчанка & 9 & 9 & 9 & 9 & 9 & 9 & 9 & 9 & 9,0 & 9,0 \\
\hline LPP 2793 & 9 & 9 & 7 & 7 & 9 & 9 & 9 & 9 & 8,5 & 8,5 \\
\hline LPP 1314 & 9 & 9 & 9 & 9 & 9 & 9 & 9 & 9 & 9,0 & 9,0 \\
\hline LPP 3118 & 9 & 9 & 9 & 9 & 9 & 9 & 9 & 9 & 9,0 & 9,0 \\
\hline P 7 & 9 & 9 & 9 & 9 & 9 & 9 & 9 & 9 & 9,0 & 9,0 \\
\hline NAK46/12 & 9 & 9 & 9 & 9 & 9 & 9 & 9 & 9 & 9,0 & 9,0 \\
\hline NAK61/12 & 9 & 9 & 9 & 9 & 9 & 9 & 7 & 9 & 8,5 & 9,0 \\
\hline$H I P_{05}$ & 1 & 1 & 1 & 1 & 1 & 1 & 1 & 1 & 0,4 & 0,5 \\
\hline
\end{tabular}

Примітка: 1 - нелущене зерно, 2 - лущене зерно. 


\section{СІЛЬСЬКЕ ГОСПОДАРСТВО. РОСЛИННИЦТВО}

Проте колір цього продукту змінювався від коричневого до світло-кремового 3 жовтим відтінком. Слід відзначити, що колір екструдату із зерна сортів Паннонікус, Кулундинка, Ac Meckinon, ліній, отриманих гібридизацією $T r$. aestivum / Tr. spelta та Tr. aestivum/амфіплоїд (Tr. durum / Ae. tauschii), і лінії Уманчанка мав світло-кремовий відтінок, який не змінювався залежно від лущення зерна. Екструдат із лущеного та нелущеного зерна цих сортів і ліній мав також дуже ніжну консистенцію.Найвищу кулінарну оцінку забезпечує використання нелущеного та лущеного зерна сорту Паннонікус, ліній Уманчанка, LPP 2793, LPP 3118, LPP 1314, P 7 i NAK46/12 - 9 балів. Лущення зерна решти сортів і ліній забезпечувало дуже високу та високу кулінарну оцінку екструдату - 7,5-8,5 балів.

Зазвичай гліадин і глютенін білка пшениці визначають якість готового продукту. Рівень його кулінарної оцінки залежить від вмісту цих фракцій білка. Крім цього, якість глютеніну впливає на властивості крупи під час варіння і покращує кулінарну оцінку готового продукту. Проте цей зв'язок існує не завжди, оскільки фракційний склад білка сортів пшениць різний [1].

Обраховано, що між запахом, смаком і конси-

\section{БІБЛІОГРАФІЯ}

1. Голик В. C. Селекция Triticum durum Desf. : монографія / В. С. Голик. - Х., 1996. - 387 с.

2. Запаренко Г. В. Характеристика спельти, як альтернативної зернової сировини хлібопекарського виробництва / Г. В. Запаренко, С. Г. Олійник, О.В. Самохвалова // Актуальні проблеми розвитку харчових виробництв, готельного, ресторанного господарств i торгівлі : матеріали Всеукр. наук.-практ. конф. молодих учених i студентів. - Х. : ХДУХТ, 2011. - Ч. 1. - С. 63.

3. Использование древних видов пшеницы для укрепления иммунной системы детского организма [Темирбекова С. К., Ионов Э. Ф., Ионова Н. Э. и др.] // Аграрное обозрение. - 2014. №6. - С. 40-42.

4. Мерко I. Т., Моргун В. А. Наукові основи технології зберігання i переробки зерна / I. Т. Мерко, В. А. Моргун. - Одеса, 2001. - 207 с.

5. Основи наукових досліджень в агрономії [Єщенко В. О., Копитко П. Г., Опришко В. П., Костогриз П. В. ]. - К., 2005. - 286 с.

6. Осокіна Н. М. Порівняльна оцінка круп'яних властивостей зерна озимої пшениці та ярих тритикале і ячменю / Н. М. Осокіна, К. В. Костецька, О. П. Герасимчук // Збірник наукових стенцією каші, отриманої з крупи цілої, подрібненої і манної та вмістом білка існує помірний кореляційний зв'язок $(\mathrm{r}=0,41-0,46)$. Проте між запахом, смаком і консистенцією каші, отриманої з крупи цілої, подрібненої і манної та вмістом фракції білка гліадин + глютенін існує істотний кореляційний зв'язок $(\mathrm{r}=0,59-0,63)$. Очевидно, що 3 підвищенням вмісту гліадину та глютеніну покращуються кулінарні властивості круп'яних продуктів.

Висновок. Круп'яні властивості зерна істотно змінюються залежно від сорту та лінії пшениць. Вихід круп'яних продуктів залежить від вмісту ендосперму. Високий вихід крупи (85-89 \%) та високу кулінарну оцінку (7-9 балів) має зерно сортів пшениці м’якої Ужинок, Вдала, Щедра нива, Паннонікус, Емеріно, Лупус, лінії пшениці щільноколосої Уманчанка і ліній, отриманих гібридизацією Tr. aestivum / Tr. spelta. Екструдування зерна пшениць істотно покращує кулінарну оцінку готового продукту завдяки температурному обробленню. Зерно сортів Кохана, Вдала, Лупус, Емеріно, Паннонікус, Ac Meckinon, Кулундинка, лінії Уманчанка та ліній пшениці м'якої озимої можна використовувати для екструдування без його лущення.

праць Уманського національного університету садівництва. - 2012. - Випуск 77. - С. 127-133.

7. Соч С. М., Кустов I. О. Крупа вівсяна плющена $з$ голозерного вівса. Наукові праці ОНАХТ / С. М. Соц, I. О. Кустов. - 2012. - Вип. 42. T. 1. - C. 33-35.

8. Chaddock R. E. Exercises in statistical methods / R. E. Chaddock. - Houghton, 1952. - 166 p.

9. Hoseney R.S. Structure of cereals / R. S. Hoseney // In Principles of cereal Sciense and Technology; American Association of cereal Chemists: St. Paul, MN. - 1994. - P. 1-28.

10. Piekut $M$. Wybrane aspekty zachowań studentów ekonomii na rynku produktów zbożowych / M. Piekut // Przegląd Zbożowo-Młynarski. - 2007. - №10. - P. 4-8.

11. Reynolds M. P. Challenqes to international wheat improvement / M. P. Reynolds, P. R. Hobbs, H. J. Braun // Aqreecultural Sciens. - 2007. - №3. C. 225-227.

12. Ruibal-Mendieta N. L. A comparative analysis of free, bound and total lipid content on spelt and winter wheat whole meal / N. L. Ruibal-Mendieta, D. L. Delacroix, M. Meurens // J. Cereal Sci. 2002. - №35. - P. 337-342. 